

\section{Imprint}

\section{Ruhr Economic Papers}

Published by

RWI - Leibniz-Institut für Wirtschaftsforschung

Hohenzollernstr. 1-3, 45128 Essen, Germany

Ruhr-Universität Bochum (RUB), Department of Economics

Universitätsstr. 150, 44801 Bochum, Germany

Technische Universität Dortmund, Department of Economic and Social Sciences

Vogelpothsweg 87, 44227 Dortmund, Germany

Universität Duisburg-Essen, Department of Economics

Universitätsstr. 12, 45117 Essen, Germany

\section{Editors}

Prof. Dr. Thomas K. Bauer

RUB, Department of Economics, Empirical Economics

Phone: +49 (0) 234/3 2283 41, e-mail: thomas.bauer@rub.de

Prof. Dr. Wolfgang Leininger

Technische Universität Dortmund, Department of Economic and Social Sciences

Economics - Microeconomics

Phone: +49 (0) 231/755-3297, e-mail: W.Leininger@tu-dortmund.de

Prof. Dr. Volker Clausen

University of Duisburg-Essen, Department of Economics

International Economics

Phone: +49 (0) 201/1 83-3655, e-mail: vclausen@vwl.uni-due.de

Prof. Dr. Ronald Bachmann, Prof. Dr. Manuel Frondel, Prof. Dr. Torsten Schmidt, Prof. Dr. Ansgar Wübker

RWI, Phone: +49 (0) 201/81 49-213, e-mail: presse@rwi-essen.de

\section{Editorial Office}

Sabine Weiler

RWI, Phone: +49 (0) 201/81 49-213, e-mail: sabine.weiler@rwi-essen.de

\section{Ruhr Economic Papers \#901}

Responsible Editor: Ronald Bachmann

All rights reserved. Essen, Germany, 2021

ISSN 1864-4872 (online) - ISBN 978-3-96973-042-3

The working papers published in the series constitute work in progress circulated to stimulate discussion and critical comments. Views expressed represent exclusively the authors' own opinions and do not necessarily reflect those of the editors. 
Ruhr Economic Papers \#901

Timothy W. Guinnane and Jochen Streb

\section{The Introduction of Bismarck's Social Security System and Its Effects on Marriage and Fertility in Prussia}


Bibliografische Informationen

der Deutschen Nationalbibliothek

The Deutsche Nationalbibliothek lists this publication in the Deutsche Nationalbibliografie;

detailed bibliographic data are available on the Internet at http://dnb.dnb.de

RWI is funded by the Federal Government and the federal state of North Rhine-Westphalia.

http://dx.doi.org/10.4419/96973042

ISSN 1864-4872 (online)

ISBN 978-3-96973-042-3 
Timothy W. Guinnane and Jochen Streb ${ }^{1}$

\title{
The Introduction of Bismarck's Social Security System and Its Effects on Marriage and Fertility in Prussia
}

\begin{abstract}
Economists have long argued that introducing social insurance will reduce fertility. The hypothesis relies on standard models: if children are desirable in part because they provide security in case of disability or old age, then State programs that provide insurance against these events should induce couples to substitute away from children in the allocation of wealth. We test this claim using the introduction of social insurance in Germany in the period 1881-1910. Bismarck's social-insurance scheme had three pillars: health insurance, workplace accident insurance, and an old age pension. Earlier studies typically focus on the pension alone; we consider all three pillars. We find that Bismarck's social insurance system affected fertility overall only via its effects on the incentive to marry. The old age insurance by itself tended to reduce marriages, but the health and accident-insurance components had the opposite effect. For people exposed to all three pillars of social insurance, the two effects cancelled each other and the aggregate effect on fertility was muted.
\end{abstract}

JEL-Code: H55, I13, J11, N13, N33, N43

Keywords: Social insurance; pensions; fertility transition; marriage; Bismarck; Prussia

March 2021

\footnotetext{
1 Timothy W. Guinnane, Yale University; Jochen Streb, University of Mannheim. - This is a revised version of our paper "Bismarck to No Effect: Fertility Decline and the Introduction of Social Insurance in Prussia" that is in SSRN as No. 3497923. For comments and suggestions we thank two anonymous referees and the editor, as well as Martha J. Bailey, Alexander Donges, Tobias Jopp, Joshua Lewis, Katerina Piro, Paul W. Rhode, Ebonya Washington, and seminar participants at the University of Adelaide, the Australian National University, the University of Melbourne, the University of Connecticut, the Vienna University of Economics and Business, the XVIII World Economic History Conference at Boston in August 2018, and the IEHA meeting in Paris in November 2019. The German Science Foundation (DFG) funded this project as part of the Priority Program 1859 “Experience and Expectations: Historical Foundations of Economic Behavior." Guinnane thanks the Economic Growth Center (Yale University) for additional funding. We are grateful to the student assistants who helped to collect and organize the data. - All correspondence to: Timothy W. Guinnane, e-mail: timothy.guinnane@yale.edu
} 
It is no coincidence that the very first country to introduce comprehensive old age pension insurance has today fallen behind. Germans have had generations since 1889, when Bismarck introduced the insurance, to experience how one can cope with old age without having children. Pension insurance has taken over responsibility for income in old age and thus contributed significantly to the childlessness of Germans.

\section{Hans-Werner Sinn ${ }^{1}$}

\section{$1 \quad$ Introduction}

Economists have often argued that the introduction of old age pension insurance (OAP) could reduce the demand for children. ${ }^{2}$ If children represent a form of savings and insurance against the vicissitudes of life, providing alternative insurance should induce adults to substitute away from children. Today some scholars advocate social insurance, often simplistically assumed to be the same as an OAP, to reduce the demand for children in high-fertility countries. Others, such as the influential German economist Hans Werner Sinn quoted above, understand the decline of fertility in wealthy countries as an unwanted consequence of generous social insurance systems. The social-insurance/fertility nexus has a particularly undesirable consequence in countries that finance social-insurance expenditure out of current contributions (pay-as-you-go) because population aging, which is a consequence of low fertility, raises individual fiscal burdens for the shrinking group of working adults. ${ }^{3}$ We focus on the introduction of Bismarck's social-insurance system in the period 1881-1910 to ask whether the introduction of the world's first large social-insurance schemes reduced fertility in the early decades of its existence. In contrast to previous studies, we consider the effects of health and accident insurance as well as the OAP,

\footnotetext{
1 "Es ist doch kein Zufall, dass ausgerechnet jenes Land, das als erstes Land eine umfassende staatliche Rentenversicherung einführte, heute ganz hinten steht. Über Generationen haben Deutsche seit 1889, als Bismarck die Versicherung einführte, die Erfahrung gemacht, dass man auch ohne eigene Kinder im Alter zurechtkommen kann. Die Rentenversicherung hat den Menschen die Verantwortung für ihr Einkommen im Alter genommen und damit die Kinderlosigkeit der Deutschen maßgeblich mitverursacht." Handelsblatt interview with Hans-Werner Sinn, December 9, 2014.

${ }^{2}$ For early contributions see Leibenstein (1957), Neher (1971), and Becker and Barro (1988).

${ }^{3}$ Schultz (1997) surveys the evidence on the demand for children in low-income countries. Sinn (2004) argues that the pay-as-you-go pension system serves both as insurance against not having children and as an enforcement device for ungrateful children who are unwilling to support their aged parents.
} 
and thus consider all three pillars of Bismarck's program. We estimate separate models for marriage and fertility, and our fertility models address the endogeneity of infant mortality and marriage in fertility decisions. We find that Bismarck's social insurance system affected fertility overall only via its effects on the incentive to marry because, for most people, marriage continued to be a prerequisite for having children. The OAP by itself tended to reduce marriages (and therefore fertility). The health and accidentinsurance components had the opposite effect. For people exposed to all three pillars of social insurance, the two effects cancelled each other and the aggregate effect on fertility was muted.

The second half of the nineteenth century in Europe witnessed two of the great transformations that created our modern world. One was demographic. Europeans began to marry at earlier ages and in larger proportions than in the past. Women had fewer children, and more of those children survived childhood. The introduction of social insurance marked a second transformation: to supplant locally organized and financed, highly discretionary programs, European governments introduced national schemes that provided well-defined benefits triggered by events such as illness, accident, or old age. This paper studies the effect of the second transformation on the first. The German fertility transition clearly began before the introduction of social insurance, but the German economist Sinn is not alone in arguing that social insurance contributed to fertility decline and the below-replacement fertility found in many wealthy countries today. German Chancellor Otto von Bismarck's three-pillar program of health insurance, workplace accident insurance, and old age pensions was among the earliest and most extensive of European social-insurance programs. The system covered virtually all workers in specific sectors, and, over time, included most of the workforce. German social insurance appeared with a bang: compulsory health- and accident-insurance programs created in 1884 and 1885 covered some 29 and 50 percent of all workers, respectively, and the old age pension insurance (1891) initially applied to 58 percent of workers. ${ }^{4}$ We focus on the state of Prussia, which accounted for about two-thirds of the entire German population in

\footnotetext{
${ }^{4}$ Throughout we refer to the years an insurance program came into force. Thus the health-insurance law passed the Reichstag in 1883 but did not operate until 1884, and the accident-insurance law was enacted in 1884 but put into force in 1885. The OAP law was passed in 1889 and started operating in 1891.
} 
1880. The insurance rules were common to all the German states, and Prussia has high-quality demographic and other data that justify restriction to this state.

The introduction of social insurance in Germany offers a chance to study the demographic impact of social insurance free from some important complicating influences. Bismarck pushed social insurance to achieve larger political goals, including alienating the German working class from social democracy. No major economic crisis took place in the period we study, and, Germany experienced peace until $1914 .^{5}$ Studies of social insurance's impact in other countries, on the other hand, present complications because of program design or the historical context of introduction. The U.K.'s old age pension (1908), for example, was at first means-tested and thus affected only parts of the population. The U.S. Social Security system (enacted in 1935) has also received considerable attention. The U.S. program was simpler than its U.K. counterpart, but came into being during the Great Depression. ${ }^{6}$

The demographic context also provides a more realistic test in the German case. While the fertility transition in Germany pre-dated the social insurance system, fertility was relatively high when Bismarck's program came along. This contrasts with other cases. For example, by 1908 (for the U.K.) and especially by 1935 (for the U.S.), fertility had already declined considerably. ${ }^{7}$ Figure 1 reports the crude birth rate and crude marriage rate for Prussia for 1880 to 1910 . From 1880 to 1895 , the crude birth rate declined by about ten percent; the pace of decline picked up thereafter. ${ }^{8}$ Figure 1 also reveals that marriage rates increased in the late nineteenth century. The latter development is usually explained by the relaxation of

\footnotetext{
${ }^{5}$ For the political dimensions of the social-insurance program see Wehler (1995, pp. 907-915) and Frerich and Frey (1996, p. 91). An earlier historiography viewed the 1880s as a "Great Depression," but that view reflected a confusion of falling prices with falling real output. Hoffmann (1965)'s and Burhop and Wolff (2005)'s GDP estimates imply steady growth throughout the 1880s. Burhop and Wolff (2005, Figure 16) see the late 1870s and 1880 s as a business-cycle upswing.

${ }^{6}$ For both the U.K. and the U.S., the advent of a world war soon after program introduction also complicates efforts to understand these programs' long-term impacts.

${ }^{7}$ The Total Fertility Rate (TFR) measures the number of children a woman would bear in her lifetime if she survived to the end of child-bearing years and experienced the current age-specific fertility at each age. According to Coale and Zelnik (1963, Table 2), the TFR for the white U.S. population first fell below 3.0 in 1922, was 2.6 in 1928 (before the onset of the Depression), and by 1935 was 2.14. David and Sanderson (1987) argue that for decades U.S. birth-controllers had shown strong evidence of a two-child norm. Fertility of African-Americans was higher, in part because they were at this point more rural, but the trends are similar to whites (Coale and Rives (1973)).

${ }^{8}$ Marschalk (1984, p. 157) reports TFR for Germany as a whole in $1881 / 90$ as 4.93 and in 1891/1900 as 4.78.
} 
marriage restrictions that we describe below. It has been an open empirical question whether these demographic changes were accelerated by the introduction of Bismarck's social insurance system.

[Insert Figure 1 about here]

Most empirical studies of other times and places find a negative relationship between the generosity of a social security system and fertility. The strength of this negative correlation, however, seems to depend on the concrete historical conditions. Boldrin et al (2015) assume that OAP began to affect fertility considerably only after World War II when, in the US and Europe, pensions eventually reached a level that allowed retirees to maintain their previous standard of living. Galasso et al (2009) argue that social security's effects on fertility are smaller in countries with an already well-developed financial sector where the introduction of OAP led households to reduce their private savings rather than the number of their children. ${ }^{9}$ Other studies imply that fertility rates react to major changes in the social security system only with some delay. Holmqvist (2011), who studied OAPs in sub-Saharan Africa, suspects that household behavior does not respond to a fundamental pension reform until people have verified that the promised benefits will actually be paid. Danzer and Syska (2020) observe that young Brazilian women continued having babies after a major pension reform in 1991 until they reached their planned, but downwardly revised, number of children. Ehrlich and Kim (2006) consider social security's impact on marriage rates. They show for a panel of 57 countries in the period 1960-1991 that an increase in social security contributions reduced incentives to marry, which in turn reduced the fertility rate. ${ }^{10}$

Researchers have only recently considered the effects of Bismarck's social insurance system. ${ }^{11}$ Jopp $(2011,2012,2013)$ studies the earlier miner's social-insurance system (the Knappschaften) which was the model for Bismarck's program. Fenge and Scheubel (2017) (which builds on Scheubel (2013))

\footnotetext{
${ }^{9}$ Based on a VAR model, however, Cigno et al (2003) find that an increase in social security coverage had a negative impact on fertility but a positive effect on households' private savings in Germany in the second half of the twentieth century.

${ }^{10}$ Jäger (2017) studies the impact of public pensions on fertility in several European countries. He uses aggregate, national-level data on fertility. Germany is not in his dataset.

${ }^{11}$ For a review see Jopp and Streb (2021).
} 
marks the first empirical test of the social-insurance/fertility nexus for Germany. They claim that the introduction of old age pensions in 1891 accounts for 15 percent of the observed fertility decline in the German Empire in the late nineteenth century. We, in contrast, find essentially no effect. These contradictory results reflect different methods as well as our focus on Prussia alone. Fenge and Scheubel (2017) make some modelling choices that may account for their results. Most notably, they ignore the demographic impact of both infant mortality decline and the relatively generous accident insurance system. They also treat marriage rates as exogenous. We discuss this research more below.

Elsewhere we have studied other implications of Bismarck's program. Guinnane and Streb (2015) demonstrate that accidence insurance decreased the number of workplace deaths and injuries. LehmannHasemeyer and Streb (2018) show that social security crowded out private savings, just as has been argued for the U.S. social security system (Feldstein 1974). Bauernschuster et al (2020) consider the health insurance system's effect on health outcomes per se. Khoudour-Castéras (2008) shows that workers valued social insurance in the sense that for a given U.S.-German wage differential, German emigration rates became smaller after 1883. A much larger literature discusses related issues in other countries. The best-developed case is the United States, for which Fishback, Kantor, and co-authors have studied several issues related to the design and execution of the workmen's compensation system (the U.S. analogue of Germany's accident insurance system) as well as a broader range of questions dealing with relief programs under Roosevelt's "New Deal.",12

Our contribution also relates to the growing body of research that uses Prussian county-level data to analyze the causes and consequences of human capital formation in the 19th century. Becker and Woessmann $(2008,2009)$ show that Protestant families invested more than Catholics in the education of their children both male and female. Becker et al $(2012,2013)$ observe a negative relationship between education and fertility in the period before the demographic transition. Cinnirella and Streb (2017) suggest

\footnotetext{
${ }^{12}$ Fishback et al (2007) study the effect of relief policies during the Great Depression, and thus is thematically closest to this paper. They contend with a much richer and more complicated set of policies than characterized German social insurance in the early days. For the workman's-compensation project see Fishback and Kantor (2007). See also Fishback et al (2010).
} 
that in regions with fast technological progress parents reduced fertility faster (and invested more in their few children's education) than in regions where innovations were rare.

This paper's identification strategy relies on the fact that Bismarck's social insurance rolled out in stages and covered all members of different occupational groups to varying degrees. For example, we can isolate the demographic effects of health insurance by comparing the demographic behavior of farm workers, who were only covered by accident insurance and OAP but not by health insurance, to that of industrial workers, who profited from all three pillars of Bismarck's social insurance system. To understand this approach, it is crucial to comprehend how Bismarck's program evolved. Section 2 provides this background. Section 3 discusses the data and the identification strategy, while section 4 presents the empirical results regarding marriage and fertility. Section 5 concludes.

\section{$2 \quad$ Historical background}

\section{Germany's fertility transition}

The demographic changes we study took place within a larger context. Fertility decline was panEuropean; an explanation of fertility decline cannot rest solely on some fact peculiar to Germany. Princeton University's European Fertility Project (EFP) implies that the German fertility transition began in the 1870 s or 1880 s. The EFP relied on highly aggregated data and a particular set of indices. Other studies that rely on individual-level fertility histories find evidence of fertility control earlier in the nineteenth century. ${ }^{13}$ We need not take a position on the details underlying these discrepancies. For us, the key point is that by 1880 , the fertility transition in Germany was clearly underway. The question is whether the Bismarck's social insurance accelerated the fertility decline.

Testing the effect of social insurance on fertility requires attention to an important feature of the demographic regime. At least as far back as Malthus, scholars have noted that Europeans controlled births

\footnotetext{
${ }^{13}$ Knodel (1974) is the Princeton Project's contribution on Germany. The EFP dated each country's fertility transition as the first year for which marital fertility was at least ten percent below its observed maximum. See Guinnane et al (1994) for the limitations of this approach. Knodel (1988, Table 11.1) reports the Coale-Trussell "m" index of stopping for a selection of German villages. Couples in some of these communities controlled their fertility as early as 1800-24; nearly all of the communities show evidence of control by the marriage cohorts 1825 to 1849 .
} 
in aggregate by limiting access to marriage and stigmatizing births to single mothers. Rather than controlling marital fertility, that is the number of children born to married couples, Europeans controlled nuptiality.${ }^{14}$ During the European fertility transition, as married couples reduced their fertility, young people began to marry earlier and more of them married. Germany was no exception. In the period 18711910, the average age at marriage for both men and women fell by one year, and the proportion of both men and women who never married fell by about 15 percent. These changes in marriage patterns offset the decline in marital fertility significantly. A simple counter-factual calculation implies that the overall fertility decline in the period 1867-1910, about 20 percent, would have been 28 percent had marriage patterns not changed. ${ }^{15}$ Throughout this paper, we treat marriage and marital fertility separately, reflecting two distinct potential channels from the social-insurance programs.

\section{Three pillars of social insurance}

All three pillars extended compulsory coverage to workers defined by occupational groups. Table 1 summarizes each scheme's contributions and benefits. Each program differed in the benefits it offered and the financing of its costs. Table 2 lists the occupation groups included in each round of the system's extension, including those that took place after our period. The groups A-G (which are our creation) aggregate these occupations into treatment groups discussed below.

[Insert Table 1 about here]

\footnotetext{
${ }^{14}$ The use of marriage to control fertility reflects either reluctance to use available contraceptive methods, the expense and unreliability of the methods available, or fixed costs to establishing new households. For more on the fertility transition and the pre-transition regime, see Guinnane (2011). For an elegant statement of Malthusian thinking, see Wrigley and Schofield (1981).

${ }^{15}$ According to Knodel (1974, Table 2.14), male age at first marriage declined from 28.8 to 27.9, and female age at marriage from 26.3 to 25.3. Proportions never-married at age 50 fell from 9.3 to 7.9 percent for males and 11.9 to 10.4 percent for females. The counter-factual calculation in the text uses the EFP indices as reported in Knodel (1974, Table 2.1); we re-compute " $\mathrm{I}_{\mathrm{f}}$ " for 1910 using the 1910 value of $\mathrm{I}_{\mathrm{g}}$ and the 1867 value of $\mathrm{I}_{\mathrm{m}}$. To appreciate the importance of an apparently small reduction in the mean age at marriage, consider that the age-specific annual marital fertility rate would be in the range .4-.5 births for women in their twenties (see, for example, Knodel (1974, Table 10.2)).
} 
The health insurance system (which came into effect in 1884) relied on thousands of funds that organized medical insurance in their region. Benefits included partial replacement pay for those unable to work because of illness as well as doctor's fees, hospitalization, and drugs and other therapies. Workers split the cost of their medical coverage with their employers. The law permitted health insurance funds to extend benefits to the spouses and children of covered workers. Unfortunately, we do not have data on how common this practice was; as late as 1914, only slightly more than half of sampled funds did so, suggesting the practice was a first rare. ${ }^{16}$

The accident insurance system created not-for-profit mutual insurance funds (Berufsgenossenschaften) that combined firms in similar industries into one organization. The funds provided partial replacement pay for covered persons unable to work because of an on-the-job injury. Accident insurance also paid for medical care, hospitalization, rehabilitation, and other medical therapies. Disabled workers received partial or full pensions, depending on their injury, and the system paid survivor benefits to widows and orphans. Benefits under this program could be substantial. A contemporary publication gives the example of a mason whose workplace accident left him fully disabled. Assuming an annual working income of 1,391.7 Marks, the insurance program would pay him 928.2 Marks annually for life, or 835.2 Marks annually to his widow if he died. The former figure reflects a 2/3 replacement rate. Covered workers did not contribute financially to the accident-insurance system. ${ }^{17}$ Accident insurance provided benefits to illegitimate children only if their mother was covered.

The OAP provided monthly payments to workers who had reached age 70 or who demonstrated a physical inability to earn a subsistence wage earlier in life. It is important to note that Bismarck's socialinsurance system distinguished two types of invalidity. The first type of invalidity was caused by a workplace accident, and fell to the accident insurance system. The second type comprised all other causes of invalidity and was the responsibility of the old age pension insurance. Covered workers contributed to

\footnotetext{
${ }^{16}$ Fifty-six percent of a sample of 325 local health insurance funds fully covered medical for spouses and children (Jahrbuch der Krankenversicherung, 1915, p. 218). See also Hausen (2013, p. 234).

${ }^{17}$ The example is reported in Lass (1904, p. 15), which was printed for the 1904 St. Louis World's Fair. Guinnane and Streb (2015) discuss the allocation of costs between the sickness and accident-insurance systems. An injured worker was temporarily the sickness fund's responsibility. The legislation creating the accident insurance system undid an earlier liability system; covered workers could no longer sue their employers for damages.
} 
the OAP; contributions depended on working income, and benefits depended on their contributions. Mortality conditions at the time made reaching age 70 less likely than it is today. Ballod (1899, p.130) reports life expectancy at age 20 in the years $1890 / 91$ of 37.3 years for men and 41.7 for women. Only about 30 percent of men aged 20 would survive to age 70 , at which point they could expect another 7.3 years of life. ${ }^{18}$

In our period, benefits under this third pillar were meager. Annual pensions came to about 18 percent of the average worker's wage - far less than the 67 percent replacement granted by the accidentinsurance system. Old-age pensions were at first more common than those the pension funds granted on the grounds of disability, and they paid on average slightly more. In 1895, about one in every 200 Germans received something from the 1891 program. ${ }^{19}$ Although the comparatively low old-age insurance pensions were not sufficient to ensure subsistence, they helped to improve the living conditions of those affected by old-age poverty. Whether they were high enough to make children seem dispensable as oldage security remains an open empirical question.

[Insert Table 2 about here]

The three pillars covered all blue-collar workers in affected sectors. White-collar workers (Angestellte), on the other hand, came under the system only if their annual income did not exceed 2,000 Marks. This income ceiling excluded few white-collar workers in our period. While we know of no estimates for the 1880s, Kocka (1981) reports that in 1903, 68.3 percent of male and 93.6 percent of female white-collar workers were covered by social insurance. Wage growth in the decade between the

\footnotetext{
${ }^{18}$ The mortality figures are for mid-size cities (Mittelstädte). The survival number is for 1895-6. Fenge and Scheubel (2017, p.97) cite a different figure, which is for the cohort born in the year the old age pension was introduced.

${ }^{19}$ For the pension in comparison to workers' wages, see Kaschke and Sniegs (2001, Table A6, p.57). For numbers of pensions in force, Kaschke and Sniegs (2001, Table C1, p.96, and C12, p.135). The number of invalidity pensions spiked in the early twentieth century, to about 864 thousand in 1910 (compared to 96 thousand old-age pensions).
} 
introduction of insurance and 1903 implies that relatively more white-collar workers were covered at outset. $^{20}$

\section{The demographic implications of social insurance}

Each pillar of Bismarck's social insurance affected marriage and fertility decisions differently. We find it useful to distinguish between incentives to marry, on the one hand, and incentives to have a large family on the other. Since the demand for marriage derives partly from the demand for children, the distinction largely reflects whether individuals want to have any children (that is, to marry) versus a lot of children (that is, whether to control fertility within marriage). The first-order effect of all three programs was to stabilize incomes in the face of uncertain events. All three entailed implicit or explicit taxes and so slightly reduced disposable incomes. One of them altered the marginal cost of a child and thus promoted larger families. All three arguably provided some of the substitute for children that Sinn and others think has driven fertility so low in our world.

Health insurance's partial replacement pay and free medical care stabilized income for covered workers. ${ }^{21}$ This stabilization of income is an important effect not typically accounted for either by Malthusian models or the micro-economic approach associated with Becker (1973). We stress what could happen in the "bad state," when the household's main wage-earner could not work because of illness, injury, disability, or death. The social-insurance system, like any insurance system, was designed to reduce the bad consequences of life's unpredictable events. While it implied some taxes, it otherwise had little effect on incomes in the "good state." Partial replacement pay especially was a central feature of both the health- and accident-insurance systems, and reflects a period during workers rarely earned enough to self-insure against these events. The replacement wages meant a family need not face penury if the primary wage-earner, in this period nearly always a male, could not work due to illness or injury.

\footnotetext{
${ }^{20}$ White-collar workers in all were a small part of the workforce, 1.9 percent of the total in 1892 and 3.3 percent in 1895 (Kocka 1981, p.17, note 13). The estimate of insurance coverage appears on page 136, note 71.

${ }^{21}$ Note that this effect differs from standard Malthusian thinking, in which the demand for marriage is a positive function of the real wage. However, the demand for marriage also depends on the second moment of real wages.
} 
Contemporaries stressed this issue in connection with the earlier miner's insurance (Jopp, 2011, 2012, 2013). By stabilizing worker incomes, health insurance promoted marriage. A man who could provide for his family even when unable to work was a more attractive husband. ${ }^{22}$ Until the program extended coverage to children, however, health insurance did not change the marginal cost of an additional child to a married couple. Any effect on family size alone must therefore run through a channel that connects earlier marriage to larger families.

The accident insurance system's rules imply different effects on demographic decisions. The system stabilized worker incomes in the same way as health insurance. This would have similar effects: men whose families would not suffer if he was injured were more suitable husbands, inducing more marriages. Severely-injured workers also received disability pay for life, and the system paid benefits to the widows and children of workers killed on the job. This feature stabilized family income in the face of the wage-earner's possible death or permanent disability, and once again promoted marriage; a woman married to a covered worker knew that if her husband died on the job, she would receive payments for life, and thus did not need to worry that she would be left to fend for herself and her children alone. The incentives regarding marital fertility are more complex. Because young children also received survivor's pensions, the accident-insurance system reduced the expected marginal cost of a child by covering childrearing costs if their father died. On the other hand, because the accident insurance scheme included a pension, couples had an incentive to reduce family sizes via the channel emphasized by economists. Given the countervailing effects, we cannot sign the net effect $a$ priori.

The accident insurance system implied an additional wrinkle. The system only paid benefits to the covered individual's legitimate children. Under German law, however, a child became legitimate when the

\footnotetext{
${ }^{22}$ Gegenüber dem Proletarier ,,verfügte der Bergmann über eine gesicherte Existenz und hinreichende Altersversorgung, [...] er erfreute sich in weiten Kreisen der allgemeinen Hochschätzung und mochte daher, etwa bei der Brautwerbung, als junger Hauer erfolgreich auf die vielen Vorzüge seines Berufs hinweisen." (Tenfelde 1977, p.128) (Compared to the proletarian, "the miner had a secure existence and adequate retirement provision, [...] he enjoyed widespread general esteem and therefore, for example in courtship, drew attention to the many advantages of his job as a young miner") Tenfelde (1977) quotes another author noting "das Ansehen des 'ingeschriewenen' Hauers als zuverlässigen Versorger der Familie" ("the reputation of the 'registered' miner as a reliable provider for the family.")(p.128, note 29).
} 
two parents marry. The orphan benefits under the accident insurance system might have spurred some couples to marry after starting their families. ${ }^{23}$

In stark contrast to the accident insurance system, the OAP applied to covered workers alone; it gave widows and other survivors nothing. Thus the pension system encouraged women to acquire their own pension claims by getting a paid job. Most insured workers were male, although covered women became relatively more numerous over time. Women accounted for 18 percent of insured under the health-insurance scheme in 1885, a figure that reached 37 percent in 1914. Women comprised 34 percent of the pension insured in $1904 .{ }^{24}$ To the extent the OAP provided old-age insurance, some women might forgo marriage and children entirely and focus on labor-market earnings. This behavior can be understood as an extreme consequence of the economists' usual argument. Driven by old-age insurance, women renounced not just children, but marriage. The other important effect is that usually stressed by Sinn and other economists: the OAP provided support in old age, making children less important within marriage. These theoretical considerations suggest that an OAP with sufficient generosity may indeed have reduced incentives to marry and to have children. As we stressed above, however, in our period the OAP's payouts were too small to sustain independent households.

Note that we have described countervailing effects: for those subject to the OAP alone, the effect on marriage and fertility was negative. The other two components, especially the accident-insurance system, promoted marriage and fertility. Our econometric exercise seeks to disentangle these effects.

\section{$3 \quad$ Data and methods}

\footnotetext{
${ }^{23}$ The same argument applies to local funds that extended health insurance to spouses and children. Prussian law (even prior to the 1900 Civil Code) recognized the legitimation of children whose natural parents married (legitimation per matrimonium subsequens), provided the new husband declared himself the natural father (also filed a Vaterschaftanerkennung). The sources do not allow us to investigate whether legitimation was more common because of the accident-insurance system. Appendix H reports a check on our fertility models where we combine legitimate and illegitimate births. It matters little, but this check is not cleanly testing the hypothesis described in the text.

${ }^{24}$ See Borscheid and Drees (1988); data available from the GESIS Datenarchiv, Cologne, histat, Studiennummer 8347 and 8602. See also Hausen (1995, p. 231).
} 
We study decisions at the level of the Kreis, a small unit comparable to a U.S. county. The average Kreis had a population of about 62 thousand in 1880. Our (entirely balanced) panel has one observation per Kreis for each year in the period 1881-1910. The 1882 census of occupations includes the number of workers in each sector in each Kreis. The census's sector definitions (mostly) correspond to the groups included in the compulsory insurance system, so we use the 1882 figures to approximate the number of covered workers in each district.

Bismarck's system rolled out in stages. No Kreis was ever entirely untreated or entirely treated, so we identify program effects from differences in treatment intensity, measured as the fraction of workers covered under different combinations of programs. The three different pillars affected occupations differently, making it impossible to test the effect of any one pillar alone. When accident insurance came in 1885, it covered some workers already enrolled in the health insurance scheme and many who were not. We cannot estimate a pure "accident insurance" effect, for example, without assuming that accident insurance coverage affects everyone the same, regardless of their health insurance status. Rather, we create seven groups of occupations (A-G) defined by the complete package of coverage under the social insurance system. Group “A,” for example, consists of workers who received health insurance in 1884, accident insurance in 1885 , and the pension system in 1891 . Group " $C$ 's" farm workers never had health insurance in our period, but were enrolled in accident insurance in 1886 and the pension system in 1891 . Refer back to Table 2, which summarizes the coverage of workers in various sectors, including periods beyond those studied in this paper. ${ }^{25}$

The geography of coverage reflects the regional distribution of economic activity in Prussia (Appendix Figures C.2-C.4 report maps of insurance coverage.) Miners enjoyed a sector-specific social insurance system prior to Bismarck's program. Miners were most numerous in regions with rich deposits of coal and nonferrous metals, that is, the Rhineland, Westphalia, Saxony, and Silesia. The 1884 health-

\footnotetext{
${ }^{25}$ The Gesetz, betreffend die Pensionierung und Versorgung der Militärpersonen, sowie die Bewilligung für die Hinterbliebenen of June 27, 1871 provided that, depending on their rank, officers and enlisted soldiers were eligible for invalidity and old age pensions up to 75 percent of their pay. Eligible individuals are not a large group (unlike the veterans of twentieth-century wars). Our analysis groups the military with other covered state employees.
} 
insurance program focused on industrial workers and thus covered few people in Prussia's eastern, largely agricultural areas. On the other hand, farm workers in eastern Prussia were the main beneficiaries of the second round of accident insurance. ${ }^{26}$ The accident-insurance system's three-stage roll-out was not driven by contemporaries' political preferences. The first round, 1885, replaced the Liability Act of 1871 that had focused on factory workers. The two later extensions were part of the original plan and the necessary legislation followed as intended (Ayaß, 2001, p. XVII). The 1891 pension applied to a broader class of workers and thus was important to most Prussian areas. The exceptions were those in the western and central provinces with many self-employed farmers, who were not covered until after our period.

Insurance coverage in each Kreis reflects uniform national rules and their interaction with local occupational structure. Differences in coverage between two Kreise do not mirror efforts to reward or punish specific classes of people; they reflect differences in occupational structure that in turn reflect patterns of local comparative advantage as well as historical antecedents. Our approach demands that the industrial structure in a given Kreis affected changes in demographic decisions only via inclusion in the insurance program. Since we stress fixed-effect models, a violation would require some type of change over time, within industries, that influenced the incentive to marry and to have children. Even then, to affect our results, such changes would have to be correlated with treatment intensity. The treatment variables rely on cross-sectional differences in employment structure, which raises concerns about the role of migration. In a rapidly-developing economy one would expect changes in the relative sizes of occupations within Kreise, making the 1882 data a less-desirable proxy as time went on. The next occupation census after 1882 came in 1895 . This census offers the chance to check results against the 1882 enumeration, but the 1895 census unfortunately did not provide as much Kreis-level detail as the 1882. The social insurance scheme sharply distinguished employees from the self-employed in our period,

\footnotetext{
${ }^{26}$ The occupational classes the 1882 census of occupations do not serve us well in one particular case. The designation "Hausdienst und wechselnde Lohnarbeit" includes both domestic (household) servants and live-in farm workers (Gesinde). The former were definitely not included in the health and accident insurance systems in our period. The latter were covered under the 1886 accident insurance extension. Because we cannot distinguish the two groups in the 1882 enumeration, we assume, for the estimates reported in the text, that none of the individuals reported in this occupational group had insurance. Appendix H reports robustness checks in which we assume that large fractions of people reported in this category in rural areas were farm workers and thus were covered.
} 
and only the former were covered. The 1882 census made this distinction at the Kreis level; the 1895 did not. To undertake a robustness check using the coverage implied by the 1895 enumeration, we make an assumption that relies on the detail available one administrative level up: the Regierungsbezirk. (There were 36 of these units in Prussia. In 1890, they had an average population of about 841 thousand people, compared to an average population of 67 thousand in our 450 Kreise.) We assume that for each Kreis within a Regierungsbezirk, the self-employed proportion of an occupational group is the same as the average for the Regierungsbezirk. Appendix C reports details. Using the 1895 occupation distribution does not indicate serious differences (see appendix H).

Our estimation strategy does not entirely obviate one particular form of workers' self-selection. Suppose there were two types of workers, those who were willing to pay for insurance and those who were not. When the accident-insurance system came into being (for example), workers did not contribute directly, but the operation of labor-markets meant that wages in covered industries fell relative to those in uncovered industries. The insurance benefit became part of the compensation package in the covered sectors. Workers who were not willing to pay for insurance would find covered sectors less attractive and find work elsewhere. (Because workers covered by sickness insurance paid half their cost of their insurance, the argument would be the same but the magnitudes different.) If the preferences for marriage or fertility were uncorrelated with willingness to pay for insurance, then this type of sorting does not affect our results. If not, our estimates partially reflect sorting into and out of covered industries. The contemporary discussions do not mention this issue.

Our strategy reflects data limitations. There is no occupation-specific demographic data available on an annual basis in this period. Our dependent variables reflect marriage or fertility for everyone in a Kreis. This constrains our ability to identify changes due to the insurance system. We can view a demographic measure such as the CBR as the weighted sum of the (unobserved) occupation-specific CBRs in that county:

$$
C B R=\sum_{i=A}^{G} \alpha_{i} C B R_{i}
$$


where the $\mathrm{CBR}_{\mathrm{i}}$ are group-specific crude birth rates and the $\alpha$ s reflect that group's share in all occupations. We observe the overall fertility CBR and construct the shares (the $\alpha_{\mathrm{i}}$ ) from the 1882 census, but the data do not provide the group-specific $\mathrm{CBR}_{\mathrm{i}}$. As an example, the legitimate $\mathrm{CBR}$ for Prussia in 1880 was about 34.14 births per thousand people. Assume every group had the same fertility in that year; that is, all of our $\mathrm{CBR}_{\mathrm{i}}$ are equal. According to Table 2, industrial workers (group "A") accounted for about 22.75 percent of the Prussian workforce in that year. Suppose that in response to the social-insurance treatment, CBR for this industrial group fell by 10 percent. If no other group experienced a change in fertility, the overall CBR would fall by 3.414 times .2275 , or about .78 - less than one birth per thousand people. Meaningful responses to treatments may well be masked by the aggregated nature of the data.

We estimate separate models for marriages and legitimate fertility. For marriages the model has the form:

$$
\ln (\text { Marriages })=\delta+\sum_{i=1882}^{1910} \beta_{i}^{A} I_{i} S_{A}+\sum_{i=1882}^{1910} \beta_{i}^{B} I_{i} S_{B}+\cdots+\text { Controls }
$$

where we include terms for of our treatment groups $S_{A^{A}}-S_{G}$. The $I_{i}$ terms are year dummies and the $\beta$ s are the parameters to estimate. We interact each year dummy with the full set of Ss so time trends are accounted for by the interactions. The year 1881 serves as the reference year for each treatment group. The specification for fertility differs slightly, as described below.

To assess whether social insurance affects demographic behavior, we ask whether the $\beta$ s change significantly after a program introduction. Table 3 provides three example districts. The variables $\mathrm{S}_{\mathrm{A}}$ to $\mathrm{S}_{\mathrm{G}}$ are the percentage of the working population in our seven insurance groups in 1882, and the CBRs are for reference. The treatment group A (industrial workers) accounts for 39 percent of the workforce in Hagen (Ruhr) in 1882. Group C (farm workers) are only 7.5 of this Ruhr Kreis. Düren has almost as many industrial workers (Group A) as Hagen, but more farm laborers (Group C) and fewer miners (Group G). Schivelbein, in Pomerania, has few industrial workers (Group A) or miners (Group G), but more farm 
laborers (Group C) than the other two Kreise. Model identification relies on these cross-sectional differences in treatment intensity in 1882 .

[Insert Table 3 here]

Using the time-period 1881 to 1910 gives us the impact of each pillar, including the 1891 pension system. Our models have two sorts of "control groups:" the pre-program period for every Kreis as well as occupations that are not treated as of a specific year. Appendix E addresses the parallel pre-trends assumption. Using both graphical and more formal tests, we find no violations in the period we study.

Prior to Bismarck's program, some Germans participated in voluntary schemes to insure against the vicissitudes of life. Private firms offered insurance plans, and some cities, employers, and civil-society organizations offered insurance schemes. Contemporaries claimed that the new system crowded-out older schemes, but we know of no quantitative source documenting the extent of the issue. ${ }^{27}$ Some people newly affected by the social-insurance scheme might have had earlier insurance that they dropped. For such persons our estimates reflect switching to the compulsory scheme, not insurance per se. The healthinsurance system's flexibility raises a related measurement problem. Our approach assumes that all health funds had the same policies during the initial years that we study.

One could reasonably ask when a given treatment began to influence demographic decisions. Marriage and children reflect long-term commitments; when would individuals take a program as known and permanent, and make it the basis of decisions? Our reading of the political history reassures us that repealing or even scaling back the program was implausible. The more important question is when workers would begin to condition their behavior on the insurance system. Consider the health-insurance program. Bismarck outlined his plan to establish a social security system in the German parliament (Reichstag) in 1881. Parliament passed the legislation in 1883, but the local health funds did not begin

\footnotetext{
${ }^{27}$ See, for example, Ludwig Bamberger's warning to the Reichstag (Stenographische Berichte über die Verhandlungen des deutschen Reichstags, 4. Legislaturperiode, IV. Session 1881, Vol. 1, p. 675).
} 
operation until 1884. A worker covered under this scheme might have adapted to it in 1881, when Bismarck announced the general plan (that is, there might be an "announcement effect"); in 1883, when parliament passed the law; in 1884, when the health funds started operating; or perhaps later, after seeing the insurance plan in action. The original accident-insurance law focused on industrial workers. The legislative debate over the system's expansion in 1885 (that is, after the first round) reflects an agreement on extension to new groups of workers, but less agreement about which workers should be covered right away. There was no master plan for the three-stage roll-out. We think it unlikely that workers could have predicted the actual program history in $1881 .{ }^{28}$ Once in place, firms, the government, and political parties went to considerable lengths to publicize the benefits available. By the late 1890 s the cohorts in a position to consider marriage or fertility decisions had come to adulthood in a world characterized by this system.

We construct the treatment variables from the distribution of worker occupations reported in the 1882 census of occupations. The demographic variables (both the dependent variables and demographic controls) come from two sets of Prussian official data. The vital registration system reported events: births, deaths, marriages. Quinquennial population censuses report population sizes and urbanization for the period 1875 through $1910 .{ }^{29}$ Ideally, our dependent variables would be age-standardized rates that take into account the population at risk of these events, but data limitations force us to rely on approximations. Instead, we base our analysis on the counts of marriages celebrated and babies born and control for population.

The sources provide separate counts of the number of legitimate and illegitimate births. Illegitimacy remained an important feature of Prussian demographic patterns into the twentieth century.

\footnotetext{
${ }^{28}$ See, for example, the remarks by Julius Kräker, a Social Democrat, and the Liberal Karl Schrader (Stenographische Berichte über die Verhandlungen des deutschen Reichstags, 6. Legislaturperiode, I. Session 1881, Vol. 2, pp. 982-3 and 987).

${ }^{29}$ Appendix B provides more detail on the data. We use the 1882 occupational census information as reported by the Ifo Prussian Economic History Database (Becker et al, 2014). The demographic variables all come from the "Galloway Prussia Database 1861 to 1914. See Galloway (2007). Galloway used as much detail as the sources reported.
} 
While much lower than the levels observed in southern Germany, throughout our period the average Prussian Kreis saw 2-3 illegitimate births per thousand people each year. This figure varied dramatically across the country, with levels reaching eleven illegitimate births per thousand in some areas. Illegitimacy in Germany was the subject of considerable policy concern in our period, and a rich literature since has debated why it was elevated relative to other western European countries. One possible cause potentially affects our marriage estimates. Until the 1860 s, many German states legally restricted marriage, often by requiring couples to obtain permission from local authorities after demonstrating their moral and economic fitness to be parents. Not surprisingly, this politische Ehekonsens led many couples to have children without marrying. The restrictions were not as tough in "Old" Prussia as in the south German states, but some of Prussia's 1866 territorial acquisitions had only repealed the Ehekonsens in the 1860s. A marriage boom in the 1870 s reflects, in part, the end of these restrictions, and is the reason we start in 1881 instead of earlier. ${ }^{30}$

\section{Empirical models}

While we examined pooled models, we stress specifications that include Kreis and year fixed effects (the year fixed effects are interacted with the $\mathrm{S}$ terms, as shown in equation (2)). The dependent variable for all our regression models is the natural $\log$ of a count. Our demographic controls include urbanization, population size, and the number of the population that is female. We cluster all standard errors at the level of the Kreis.

Two controls in the fertility model are arguably endogenous: infant mortality and marriage. ${ }^{31}$ The literature discusses several channels that make infant mortality endogenous. One channel would be unobserved heterogeneity; couples reluctant to use contraception might tolerate more child deaths. Other arguments stress the deleterious impact of a large (possibly closely-spaced) brood on child survival.

\footnotetext{
${ }^{30}$ For evidence on the demographic implications of the politische Ehekonsens see Knodel (1967) or Guinnane and Ogilvie (2014). Ehmer (1991) provides more detail on the policy.

${ }^{31}$ With annual data, the mortality rates may in part convey information irrelevant to a decision about conception: many babies born in year $\mathrm{t}$ reflect conceptions in year $\mathrm{t}-1$. Our regressions here ignore this issue, but robustness checks reported in Appendix section H show that this wrinkle does not affect the results.
} 
Finding suitable instruments in this case is especially difficult, because most things that affect fertility also affect child survival. Marriage is endogenous for similar reasons; preferences for children influence marriage decisions.

For infant mortality we use an instrument that reflects the local disease environment. ${ }^{32}$ Many infants died because of exposure to pathogens before their immune systems were able to fight back. Infectious diseases spread via water and food contamination. The Kreis's elevation in meters captures important exogenous variation in the disease environment. Diseases such as dysentery were worse at lower altitudes because of differences in temperature (especially summer temperatures). ${ }^{33}$ The elevation variable has no variation in the time dimension, but we interact it with year. The interaction captures the changing effect of elevation as public-health measures improved. ${ }^{34}$ Violation of the exclusion restriction would require that elevation affect fertility via channels other than mortality. One could imagine subtle differences in local economies at higher elevations that might affect fertility directly, but in a fixed-effects framework this is not a major concern.

For marriage, we use the Kreis's longitude, again interacted with year. A long tradition in historical demography debates the causes of variation in historical marriage patterns in Europe. Hajnal's $(1953,1965)$ famous St. Petersburg-Trieste line puts all of Prussia on the side with the western European marriage pattern. Ehmer (1991, pp. 103-111), however, stresses that eastern Prussia had the early and nearly universal marriage typical of places on the eastern side of that line. Violation of the exclusion restriction in this case would require that longitude affect fertility directly, and not just via marriage. These two instruments yield a just-identified 2SLS model. Appendix section F reports ancillary statistics for weak- and under-identification. This just-identified model passes those tests easily. Appendix section F

\footnotetext{
${ }^{32}$ Schultz (1997, pp. 384-386) discusses this issue and provides additional references. If the issue really is unobserved heterogeneity, the FE specifications would suffice. See Brown (1988) for the improvement of publichealth systems and Spree (1981) or Brown and Guinnane (2018) for infant and child mortality. The infant mortality variable we use is for legitimate children only. We use the logit of the reported proportion: our variable is $\ln ($ INFMR/(1-INFMR)).

${ }^{33}$ Malaria is also worse at lower altitudes. Until the middle of the nineteenth century, Prussia's marshy areas supported malaria infestations. By the end of the century, Prussia had eliminated malaria, with the exception of some areas in the provinces of Schleswig-Holstein and Silesia. See Dalitz (2015, p. 2).

${ }^{34}$ Gallardo-Albarrán (2020) studies the impact of waterworks and sewerage on mortality in German cities during the period 1877-1913.
} 
also reports an over-identified model as a robustness check, along with a model that treats infant mortality as endogenous and marriage as exogenous.

Studies of fertility and its decline usually employ additional controls for economic structure, religion, and culture, among other forces thought to affect fertility. ${ }^{35}$ The models we report are in contrast relatively sparse for two considered reasons. First, some of these controls in other studies may not measure what the author intends. Galloway et al (1994), for example, use an "insurance" proxy that is the number of employees of insurance firms. They intend this as a proxy for reliance on financial instruments, a substitute for children. At the Kreis level, this proxy surely indicates insurance company locations rather than the propensity to own insurance policies; Frankfurt has many insurance workers because many firms headquartered there, not because its people loved to buy insurance. Second, in a fixed-effects framework, such controls only matter to the extent they have year-to-year variation. Consider religion. Because few Prussians changed their religions, within-Kreis differences in religion largely reflect confessional differences in migration, fertility, or even mortality. ${ }^{36}$ Cross-sectional differences in religion that do not change will be absorbed into the fixed effects.

\section{Results}

The models include a large number of interaction terms. (The full regression results are in Appendix J). We find it simplest to interpret the results graphically and then focus on estimated differences-in-differences. We begin with marriages. Figure 2 displays the impacts and confidence intervals for groups A (industrial workers and white-collar workers), C (farm workers), and G (miners). (A and $\mathrm{C}$ are the two largest treated groups, while $\mathrm{G}$ serves as a control because these workers all had insurance prior to Bismarck.)

[Figure 2 here]

\footnotetext{
${ }^{35}$ See Brown and Guinnane (2002), Galloway et al (1994) or Scheubel (2013) for examples using German data.

${ }^{36}$ Galloway et al (1994, note 64) refers to this issue. See Brown and Guinnane (2002) for additional discussion.
} 
Recall that 1881 is the reference year for each treatment group. Thus the point-estimates for a given year tells us how much that group's marriage or fertility behavior changed between 1881 and that year. To understand the demographic changes induced by insurance treatments, however, we focus on the difference-in-differences, which tell us how the different packages of social insurance affected the different groups. Suppose we want to compare the change in Group A between 1882 and 1900 to the change in Group C over that same period. We define DD (A, C, 1900, 1882) as $\left(\mathrm{A}_{1900}-\mathrm{C}_{1900}\right)-\left(\mathrm{A}_{1882}-\right.$ $\mathrm{C}_{1882}$ ). The order of the two groups determines the sign of DD. We always subtract the earlier year from the later. Table 4 reports the p-value for the two-sided F-test that DD equals zero, along with the magnitude of DD. Table 4 uses 1882 as the base year; appendix Tables H.3 and H.4 report tests for other combinations of years. ${ }^{37}$

[Table 4 here]

The DD in Table 4 illustrate one reason to divide the insurance treatments into six categories as we have. Group A received all three of Bismarck's pillars, and had social insurance in the first year, 1884. We use it to compare "full Bismarck" to other regimes. Group F did not participate in this or any other insurance system in our period, so comparing A to F reveals the extremes of full versus no treatment. While there are significant DD for this comparison in 1905 and 1910, their magnitudes imply a difference of about .1 percent. The positive sign on DD implies that, all told, full Bismarck slightly increased the incentive to marry. The health insurance scheme never covered group $\mathrm{C}$, so comparing A to $\mathrm{C}$ amounts to a test of the health insurance system's impact for people who had accident and old-age insurance. Here the differences are statistically significant starting in 1890 , but the magnitudes are tiny. DD has again a positive sign; the A-C comparison implies that the inclusion of health insurance promoted marriage

\footnotetext{
${ }^{37}$ Because we interact all years with all of the intensity measures A-G, we have to leave out the interaction of 1881 and every intensity measure. The levels of the demographic measures for 1881 are absorbed into the constant term. Thus DD (A, C, 1900, 1881), for example, just equals $\mathrm{A}_{1900}-\mathrm{C}_{1900} ; \mathrm{A}_{1881}-\mathrm{C}_{1881}$ equals zero, by construction.
} 
relative to a package with accident insurance and OAP only. Comparing A to D isolates the combined effect of health and accident insurance. Here we have DD that are statistically insignificant.

Comparisons that involve Group A reflect the composite effect of three schemes. Comparing D to F, on the other hand, separates the effect of old-age insurance by focusing on a group that had only this insurance (D) and another that had no insurance at all (F). We find no statistically significant effect.

We also report some placebo-like tests. Groups E and G had full coverage prior to Bismarck and did not participate in that system. We would expect there to be no effect of the Bismarck system. Starting in 1900, however, marriage rates of public servants significantly decreased in comparison to those of miners. Comparing A to $\mathrm{E}$ and $\mathrm{A}$ to $\mathrm{G}$ ask whether full coverage under Bismarck's program was equivalent to the government's guarantees to civil servants (E) and the Knappschaften that insured miners (G). We observe similar effects for industrial workers and miners. Public servants faced relatively lower incentives to marry than industrial workers though. Comparing A to B invokes a different kind of placebo; the two groups had the same insurance coverage. They differ only in that B received accident insurance two years after A. As expected, we find little difference between the two groups by the 1890s.

[Figure 3 and Table 5 here]

We now turn to fertility. Figure 3 plots point-estimates and error bands for the same selection of groups in the just-identified fertility model. Table 5 reports DD estimates defined identically to their equivalents in the marriage model. The fertility model implies even less impact than the marriage model; most DD are not precisely-estimated and the few that are statistically significant have small magnitudes. In the 1900s, industrial workers (A) faced lower incentives to have children than miners $(G)$ and higher ones than construction workers (B). Taken together, the models imply that if the Bismarck program had any effect on fertility, the influence worked through marriage.

\section{Additional forms of heterogeneity}


These models all have Kreis-level fixed effects that sweep out additive heterogeneity at that level. But the model assumes common $\beta$ s for different kinds of places. One might worry that the effect of a social insurance program's introduction would differ between cities and rural areas, for example, or in different regions of Germany. Such differences could reflect information; in urban areas worker organizations might do a better job of publicizing the new programs and how to use them. The differences could also reflect differences in income level. Lehmann-Hasemeyer and Streb (2018) estimate the average annual income in eastern Prussia as about 91 percent of that in western Prussia. ${ }^{38}$ A long historiography points out that the agricultural laborers who comprise Group C, and who were most numerous in the east, were especially poor. ${ }^{39}$

We address these possible differences in two ways. Full details are in appendix section H. First, we split the sample into Kreise that were primarily urban and those that were primarily rural. With few exceptions, even the most urban areas were located in a Kreis that had considerable rural population. This makes it possible to keep all treatment groups in the same regression, but means there is no clean "urban vs rural" comparison possible. Table 6 reports differences-in-differences for marriage in urban areas where an "urban" Kreis is one where at least 30 percent of the population lived in a city in 1880. Bismarck's insurance program had greater effects on marriage in urban areas than overall. This difference reflects, perhaps, more-rapid communication in both urban areas and their immediate hinterlands. We do not find important differences between urban and rural areas for fertility. ${ }^{40}$

Our second check resonates with Prussia's place in the western European marriage pattern, which we discussed above. Prussia's eastern provinces differed considerably, both economically and socially, from her central and western provinces. One way these provinces differed was in their marriage patterns. We again split the Kreise into two groups, this time by dividing them into the eastern and western areas.

\footnotetext{
38“"Eastern" Prussia here means the Regierungsbezirke of Breslau, Bromberg, Danzig, Gumbinnen, Köslin, Königsberg, Liegnitz, Marienwerder, Oppeln, Posen, Stettin and Stralsund. Cinnirella and Streb (2017) show that eastern Prussia was also less innovative (as measured by patenting activity) than the western part of the country.

${ }^{39}$ Many of these farm workers were of Polish nationality. Wolf et al (2019) observe that differences in the distribution of Germans and Poles explain differences in income levels, savings and literacy rates at the Kreis level in eastern Prussia. Nationality might have affected marriage rates and fertility, as well.

${ }^{40}$ Because Prussia was so rural in the 1880 s, using a higher threshold creates a too-small urban subsample. Appendix $\mathrm{H}$ reports the results for rural areas defined in the same way, as well as the results for fertility.
} 
For marriage, the results for western and central Prussia look similar to our earlier results for the country as a whole. The eastern provinces, however, are somewhat different. It seems that farm workers became more attractive husbands after they were covered by the accident insurance with their generous pensions. The fertility models, on the other hand, do no suggest important differences between Prussia's eastern regions and the rest of the country. ${ }^{41}$

\section{Contrast with earlier results}

Fenge and Scheubel (2017) find that the Old Age Pension program (1891) had much larger effects than we report here. They focus on fertility differences between 1895 and 1907. Appendix I discusses these issues further and reports some checks. Because they did not make their data public, we cannot undertake a true replication study, but, as we discuss in the Appendix, we have no reason to suspect their results reflect the type of error a replication might uncover. The difference between their results and ours might reflect the fact that we study Prussia (about two-thirds of Germany) rather than Germany as a whole, as they do.

We have serious reservations about both their data and methods, however. First, because they want to use treatment information from the social insurance system, their empirical analysis relies on twenty-three enormous administrative districts as opposed to the 450 Kreise that form the basis of our estimates. Their highly-aggregated districts mean considerable efficiency loss relative to the smaller districts we use. Second, Fenge and Scheubel omit several important controls, the most important being infant mortality. In Appendix I we report models using our data that come as close as we can to their specifications. Adding infant mortality to the regression not surprisingly affects the point-estimates relating the insurance proxies to fertility. Third, they treat marriage as exogenous, even though it is also influenced by the social security system. Fourth, their specifications do not control for general time trends in fertility. Adding a dummy for the 1907, the second wave in their two-wave panel, typically reduces the

\footnotetext{
${ }^{41}$ All results for the east/west comparison are in Appendix H. We cannot assign a great deal of confidence to the fertility models for either the urban/rural or the east/west comparisons. Splitting the country makes each sub-sample smaller, and the IVs do not work as well.
} 
social-insurance system's apparent impact on fertility. ${ }^{42}$ Finally, Fenge and Scheubel take account of the health-insurance program but not the accident-insurance system. Our results demonstrate the importance of considering all three pillars of Bismarck's system.

\section{$5 \quad$ Conclusions}

Bismarck's famous social insurance system came into being during the early stages of Germany's fertility transition. Economic theories of fertility would argue that this is not pure coincidence: if couples have children in part to provide insurance against old age and infirmity, we would expect state-supported assistance to induce couples to have fewer children. Following this logic, some observers today ascribe low fertility in wealthy countries to the effect of social insurance.

Did Bismarck's program play a role in the fertility transition? Earlier research that focuses on the 1891 pension system argues that it did. In this paper, we approach the problem differently. As we stress, the first two pillars of the social insurance system, health and accident insurance, were much more generous than the 1891 old age pension and also had elements that plausibly affected marriage and fertility. This argues for considering each of the three distinct programs and for considering their effects together. Our approach uses the distribution of covered occupations to infer the intensity of treatment for each of Prussia's 450 districts. We also analyze the effect on marriages and fertility separately. At this stage in the fertility transition, marriage remained a primary regulator of fertility, and the social insurance system's incentives related to marriage were considerable.

We find that the introduction of Bismarck's social insurance system promoted marriage to a small degree, but had no effect on marital fertility. Health and accident insurance created incentives to marry and thus at least partially offset any birth-reducing effect of old age pension insurance. This result

\footnotetext{
${ }^{42}$ In her earlier, single-author work, Scheubel (2013, p.143) reports specifications with and without the dummy for 1907. The specification that includes the 1907 dummy adds several other, additional controls, so the comparison is not precise. In the specifications that include the 1907 dummy, however, the point-estimate for the insurance coverage variable is much smaller (in absolute value): -.006 instead of -.086. Scheubel's models also include stillbirths, which she uses as a proxy for infant mortality rates. Her results imply that stillbirths are positively (and significantly) correlated with fertility. This control does not appear in the results that Fenge and Scheubel (2017) report.
} 
underlines two important facts. First, the scope of benefits provided by the health and accident insurance schemes was far greater than that provided by the OAP, which initially granted only comparatively small pensions insufficient to ensure subsistence. In addition, the health and accident-insurance systems reflected the extension of older mechanisms, while the OAP was a basic social innovation to which people probably took some time to adapt. In the long term, familiarization with the OAP may have resulted in a significantly lower birth rate; in the short term, people first had to gain confidence in the new type of system. Finally, the supposed crowding-out effect of Bismarck's social insurance may have been directed more at private savings than at fertility. By the end of the 19th century, Germany's sophisticated banks, saving institutions, and cooperatives offered small savers the opportunity to provide for their old age.

Our results may reflect the limitations of the data available to us. Lacking any individual-level data, we have to rely on aggregates that may mask changes. However, our findings should give pause to those who want to blame the welfare state for low fertility. At the start of the fertility transition, a generous and compulsory social insurance scheme did not have noticeable effects on marriage or fertility. 


\section{References}

Public-use datasets

Becker, Sascha, Francesco Cinnirella, Erik Hornung and Ludger Wößmann, 2014. "iPEHD - The ifo Prussian Economic History Database." Historical Methods. A Journal of Quantitative and Interdisciplinary History 47(2): 57-66. Information, Working paper version available as CESifo Working Paper 3904.

Galloway, Patrick R., 2007, "Galloway Prussia Database 1861 to 1914", www.patrickgalloway.com

Official sources:

Hauptverband deutscher Ortskrankenkassen, ed., 1915. Geschäftsbericht des Hauptverbands 1914. (Jahrbuch der Krankenversicherung). Dresden.

Stenographische Berichte über die Verhandlungen des deutschen Reichstags. Berlin.

\section{Other sources:}

Ayaß, Wolfgang, 2001. Die Ausdehnungsgesetzgebung und die Praxis der Unfallversicherung. (Quellensammlung zur Geschichte der deutschen Sozialpolitik 1867 bis 1914, Vol 2, Part 2, edited by Peter Rassow.) Darmstadt: Wissenschaftliche Buchgesellschaft.

Ballod, Carl, 1899. Die mittlere Lebensdauer in Stadt und Land. Leipzig: Duncker \& Humblot.

Bauernschuster, Stefan, Anastasia Drive, and Erik Hornung, 2020. "Bismarck's Health Insurance and the Mortality Decline." Journal of the European Economic Association 18(5): 2561-2607.

Becker, Gary S., 1973. “A Theory of Marriage: Part I.” Journal of Political Economy 81(4): 813-846.

Becker, Gary S. and Robert J. Barro, 1988. "A Reformulation of the Economic Theory of Fertility." Quarterly Journal of Economics 103(1): 1-25.

Becker, Sascha O. and Ludger Woessmann, 2008. "Luther and the Girls. Religious Denomination and the Female Education Gap in Nineteenth-Century Prussia." Scandinavian Journal of Economics 110(4): 777805.

Becker, Sascha O and Ludger Woessmann, 2009. "Was Weber Wrong? A Human Capital Theory of Protestant Economic History." Quarterly Journal of Economics 124(2): 531-596.

Becker, Sascha O., Francesco Cinnirella and Ludger Woessmann, 2012. "The Effect of Investment in Children's Education on Fertility in 1816 Prussia." Cliometrica 6(1): 29-44.

Becker, Sascha O., Francesco Cinnirella and Ludger Woessmann, 2013. "Does Women's Education Affects Fertility? Evidence from Pre-Demographic Transition Prussia." European Review of Economic History 17(1): 24-44.

Boldrin, Michele, Mariachristina de Nardi and Larry E. Jones, 2015. "Fertility and Social Security." Journal of Demographic Economics 81(3): 261-299. 
Borscheid, Peter and Anette Drees (eds.), 1988. Versicherungsstatistik Deutschland 1750 - 1985. St. Katharinen: Scripta Mercaturae.

Brown, John C., 1988. "Coping with Crisis: The Diffusion of Waterworks in Late Nineteenth-Century German Towns.” Journal of Economic History 48(2): 307-18.

Brown, John C., and Timothy W. Guinnane, 2002. "Fertility Transition in a Rural, Catholic Population: Bavaria 1880-1910." Population Studies 56(1): 35-49.

Brown, John C. and Timothy W. Guinnane, 2018. "Infant Mortality Decline in Rural and Urban Bavaria: Fertility, Economic Transformation, Infant Care, and Inequality in Bavaria and Munich, 1825-1910.” Economic History Review 71(3): 853-886.

Burhop, Carsten, and Guntram B. Wolff, 2005. "A Compromise Estimate of German Net National Product, 1851-1913, and its Implications for Growth and Business Cycles." Journal of Economic History 65(3): 613-657.

Cigno, Alessandro, Luca Casolaro and Furio C. Rosati, 2003. "The Impact of Social Security on Saving and Fertility in Germany." FinanzArchiv 59(2): 189-211.

Cinnirella, Francesco and Jochen Streb, 2017. "The Role of Human Capital and Innovation in Economic Development: Evidence from post-Malthusian Prussia." Journal of Economic Growth 22(2): 193-227.

Coale, Ansley J. and Melvin Zelnik, 1963. New Estimates of Fertility and Population in the United States. Princeton: Princeton University Press.

Coale, Ansley J. and Norfleet W. Rives, 1973. "A Statistical Reconstruction of the Black Population of the United States 1880-1970: Estimates of the True Numbers by Age and Sex, Births Rates, and Total Fertility." Population Index 39(1): 3-36.

Danzer, Alexander M. and Lennard Zyska, 2020. "Pensions and Fertility:Micro-Economic Evidence." Cesifo Working Papers 8173.

David, Paul A. and Warren C. Sanderson, 1987. "The Emergence of a Two-Child Norm among American Birth-Controllers." Population and Development Review 13(1): 1-41.

Dalitz, Margot Kathrin, 2015. Autochthone Malaria im mitteldeutschen Raum. Dissertation, University Halle-Wittenberg.

Ehmer, Josef, 1991. Heiratsverhalten, Sozialstruktur, ökonomischer Wandel. Göttingen: Vandenhoeck \& Ruprecht.

Ehrlich, Isaac and Jinyoung Kim, 2007. "Social Security and Demographic Trends : Theory and Evidence from the International Experience." Review of Economic Dynamics 10: 55-77.

Feldstein, Martin, 1974. "Social Security, Induced Retirement, and Aggregate Capital Accumulation." Journal of Political Economy 82(5): 905-926.

Fenge, Robert and Beatrice Scheubel, 2017. "Pensions and Fertility: Back to the Roots." Journal of Population Economics 30(1): 93-139. 
Fishback, Price V. and Shawn Everett Kantor, 2007. A Prelude to the Welfare State: The Origins of Workers' Compensation. Chicago: University of Chicago Press.

Fishback, Price V., Michael R. Haines and Shawn Everett Kantor, 2007. "Births, Deaths, and New Deal Relief during the Great Depression." Review of Economics and Statistics 89(1):1-14.

Fishback, Price V., Ryan S. Johnson and Shawn Everett Kantor, 2010. "Striking at the Roots of Crime: The Impact of Welfare Spending on Crime during the Great Depression." Journal of Law and Economics 53(4): 715-740.

Frerich, Johannes and Martin Frey, 1996. Handbuch der Geschichte der Sozialpolitik in Deutschland Vol. 1: Von der vorindustriellen Zeit bis zum Ende des Dritten Reiches. Munich: Oldenbourg.

Galasso, Vincenzo, Roberta Gatti and Paola Proteta, 2009. "Investing for the Old Age : Pensions, Children and Savings." International Tax and Public Finance 16: 538-559.

Gallardo-Albarrán, Daniel, 2020. „Sanitary Infrastructure and the Decline of Mortality in Germany 18771913." Economic History Review 73(3): 730-757.

Galloway, Patrick R., Eugene A. Hammel and Ronald D. Lee, 1994. "Fertility Decline in Prussia, 18751910: A Pooled Cross-Section Time Series Analysis.” Population Studies 48(1): 135-158.

Guinnane, Timothy W., 2011. "The Historical Fertility Transition: A Guide for Economists." Journal of Economic Literature 49(3): 589-614.

Guinnane, Timothy W. and Sheilagh Ogilvie, 2014. “A Two-Tiered Demographic System: 'Insiders' and 'Outsiders' in Three Swabian Communities, 1588-1914.” History of the Family 19(1): 77-119.

Guinnane, Timothy W., Barbara S. Okun and James Trussell, 1994. "What do We Know about the Timing of Fertility Transitions in Europe?” Demography 31(1): 1-20.

Guinnane, Timothy W. and Jochen Streb, 2011. "Moral Hazard in a Mutual Health Insurance System: German Knappschaften, 1867-1914.” Journal of Economic History 71(1): 70-104.

Guinnane, Timothy W. and Jochen Streb, 2015. "Incentives that (could have) Saved Lives: Government Regulation of Accident Insurance Associations in Germany, 1884-1914." Journal of Economic History 75(4): 1196-1227.

Hajnal, John, 1953. “The Marriage Boom.” Population Index 19(2): 80-101.

Hajnal, John, 1965. "European Marriage Patterns in Perspective.” In D. V. Glass and D. E. C. Eversley (eds.), Population in History: Essays in Historical Demography. London: Hodder \& Stoughton Educational, pp. 101-143.

Hausen, Karin, 2013. “Arbeiterinnenschutz, Mutterschutz und gesetzliche Krankenversicherung im Deutschen Kaiserreich und in der Weimarer Republik. " In Karin Hansen (ed.), Geschlechtergeschichte als Gesellschaftsgeschichte. Goettingen: Vandenhoeck \& Ruprecht, pp. 210-237.

Heckman, James J., Robert J. LaLonde and Jeffrey A. Smith, 1999. "The Economics and Econometrics of Active Labor Market Programs." In Handbook of Labor Economics. Amsterdam: Elsevier, pp. 1865-2097. 
Hoffmann, Walther G. 1965, Das Wachstum der Deutschen Wirtschaft seit der Mitte des 19. Jahrhunderts. Berlin: Springer.

Holmqvist, Göran, 2011. “Fertility Impact of High-coverage Public Pensions in Sub-Saharan Africa.” Global Social Policy 11(2-3): 152-174.

Jäger, Philipp, 2017. "Bismarck in the Bedroom? Pension Reform and Fertility: Evidence 1870-2010." Ruhr Economic Papers No. 677.

Jopp, Tobias A., 2011. “Old times, better times? German Miners' Knappschaften, Pay-as-you-go Pensions, and Implicit Rates of Return, 1854-1913.” Business History 53(7): 1018-1043.

Jopp, Tobias A., 2012. "Insurance, Size, and Actuarial Risk: Empirical Evidence from Nineteenth- and Early Twentieth-Century German Knappschaften.” Financial History Review 19(1), 75-116.

Jopp, Tobias A., 2013. Insurance, Fund Size, and Concentration: Prussian Miners Knappschaften in the Nineteenth and Early Twentieth Century and Their Quest for optimal Scale. Berlin: Akademie Verlag.

Jopp, Tobias A. and Jochen Streb, 2021. "Die Einführung der Bismarckschen Sozialversicherung und ihre Folgen für die Arbeits- und Lebensverhältnisse." In Ulrich, Pfister, Jan-Otmar Hesse, Mark Spoerer and Nikolaus Wolf (eds.), Deutschland 1871. Die Nationalstaatsbildung und der Weg in die moderne Wirtschaft. Tübingen: Mohr Siebeck, pp. 267-289.

Kaschke, Lars and Monika Sniegs, 2001. Kommentierte Statistiken zur Sozialversicherung in Deutschland von ihren Anfängen bis zur Gegenwart. Vol. 1: Die Invaliditäts - und Altersversicherung im Kaiserreich, 1891 - 1913. St. Katharinen: Scripta Mercaturae.

Kersting, Felix, Iris Wohnsiedler and Nikolaus Wolf, 2020. "Weber Revisited: The Protestant Ethic and the Spirit of Nationalism." Journal of Economic History 80(3): 710-745.

Khoudour-Castéras, David, 2008. "Welfare State and Labor Mobility: The Impact of Bismarck's Social Insurance Legislation on German Emigration before World War I." Journal of Economic History 68(1): 211-243.

Knodel, John, 1967. "Law, marriage and illegitimacy in nineteenth-century Germany." Population Studies 20(3): 279-294.

Knodel, John, 1974. The Fertility Decline in Germany, 1871-1939. Princeton: Princeton University Press.

Knodel, John, 1988. Demographic Behavior in the Past: A Study of fourteen German Village Populations in the Eighteenth and Nineteenth Centuries. Cambridge: Cambridge University Press.

Kocka, Jürgen, 1981. Die Angestellten in der deutschen Geschichte 1850-1980: vom Privatbeamten zum angestellten Arbeitnehmer. Göttingen: Vandenhoeck \& Ruprecht.

Lass, Ludwig, 1904. Die Deutsche Arbeiterversicherung als soziale Einrichtung. Berlin: Asher.

Lehmann-Hasemeyer, Sibylle and Jochen Streb, 2018. "Does Social Insurance Crowd Out Private Savings? The Case of Bismarck's System of Social Insurance." European Review of Economic History 22(3): 298321.

Leibenstein, Harvey (1957). Economic Backwardness and Economic Growth. New York: John Wiley. 
Marschalck, Peter, 1984. Bevölkerungsgeschichte Deutschlands im 19. und 20. Jahrhundert. Frankfurt: Suhrkamp.

Neher, Philip A., 1971. "Peasants, Procreation, and Pensions." American Economic Review 61(3): 380389.

Scheubel, Beatrice, 2013. Bismarck's Institutions. A historical Perspective on the Social Security Hypothesis. Tuebingen: Mohr Siebeck.

Schultz, T. Paul, 1997. "Demand for Children in Low Income Countries." In Mark Rosenzweig and Oded Stark (eds.). Handbook of Population and Family Economics. Amsterdam: Elsevier, pp. 349-430.

Sinn, Hans-Werner, 2004. „The Pay-as-you-go Pension System as Fertility Insurance and an Enforcement Device." Journal of Public Economics 88, 1335-1357.

Spree, Reinhard, 1981. Soziale Ungleichheit vor Krankheit und Tod. Göttingen: Vandenhoeck \& Ruprecht.

Tenfelde, Klaus, 1977. Sozialgeschichte der Bergarbeiterschaft an der Ruhr im 19. Jahrhundert. Bad Godesberg: Verlag Neue Gesellschaft.

Wehler, Ulrich, 1995. Deutsche Gesellschaftgeschichte Vol. 3: Von der 'Deutschen Doppelrevolution ' bis zum Beginn des Ersten Weltkriegs. Munich: Beck.

Wrigley, Edward Anthony and Roger Schofield, 1981. The Population History of England, 1541-1871: A Reconstruction. Cambridge: Cambridge University Press. 
Figure 1: Births, Deaths and Marriages in Prussia, 1880-1910

Births, Deaths and Marriages in Prussia, 1880-1910

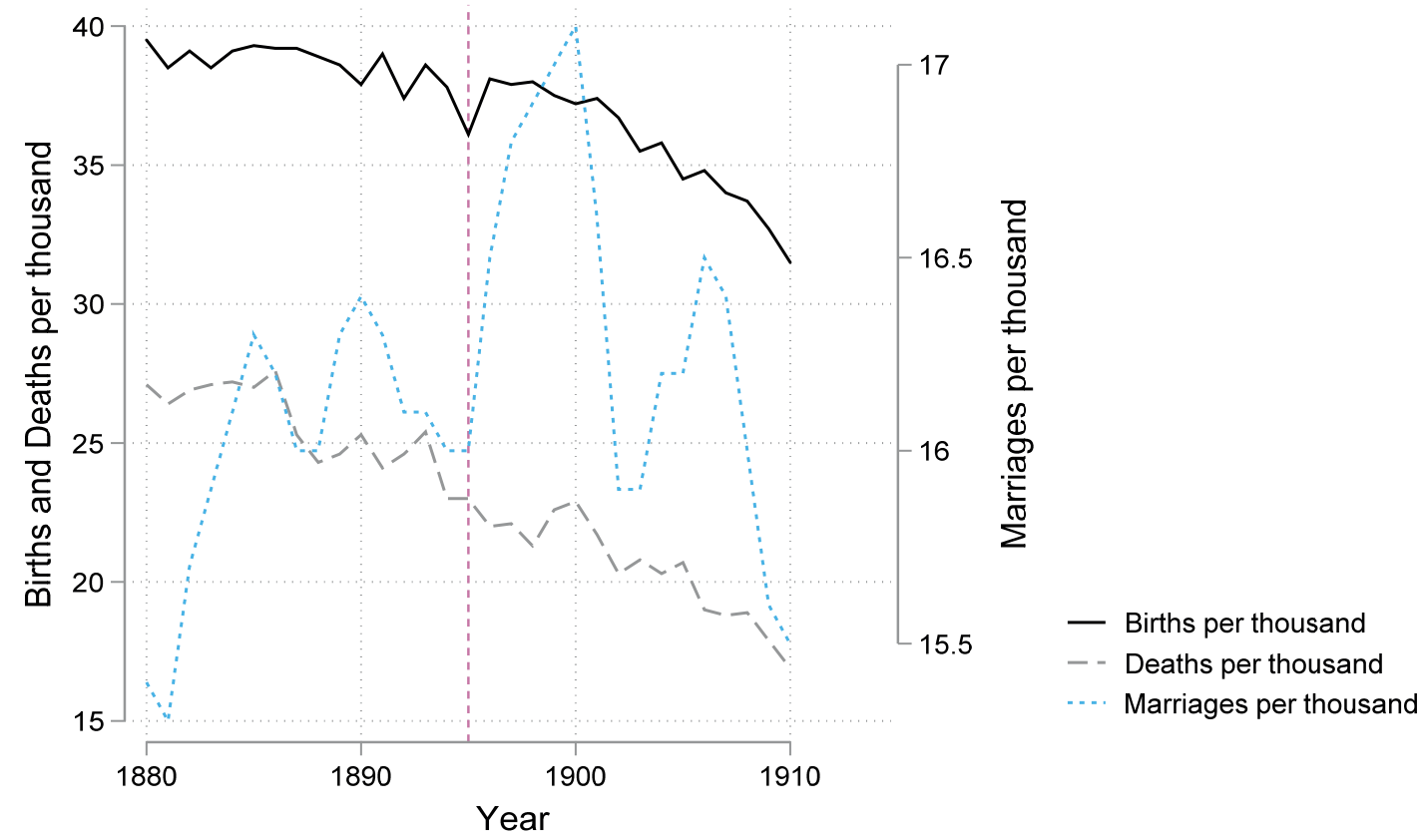


Figure 2: The effect of social insurance on marriage, all of Prussia

Social insurance's effect on marriages

All of Prussia

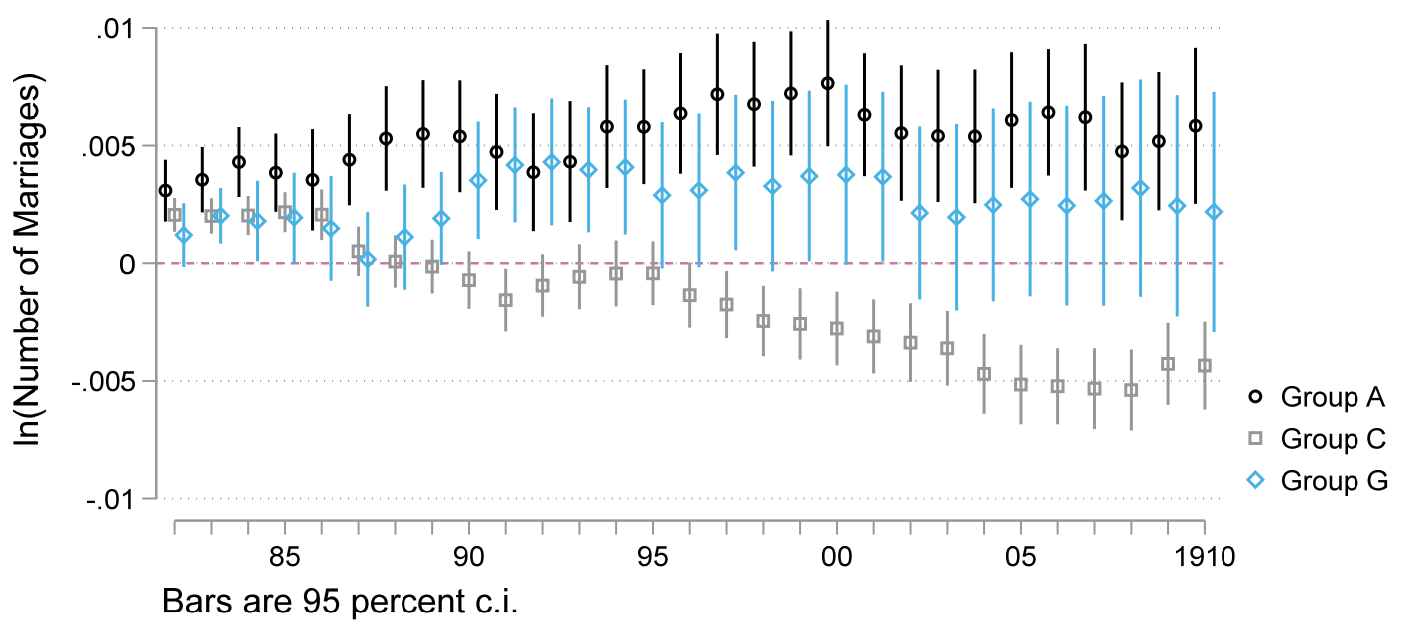

Group A: Health 1883, accident 1884, pension 1891

Group C: No health, accident 1886, pension 1891

Group G: miners (insurance pre-dates Bismarck)

Note: The figure graphs the point-estimates and 95 percent confidence intervals for the regressions discussed in the text. Regression results are in Appendix J. 
Figure 3: The effect of social insurance on fertility, all of Prussia

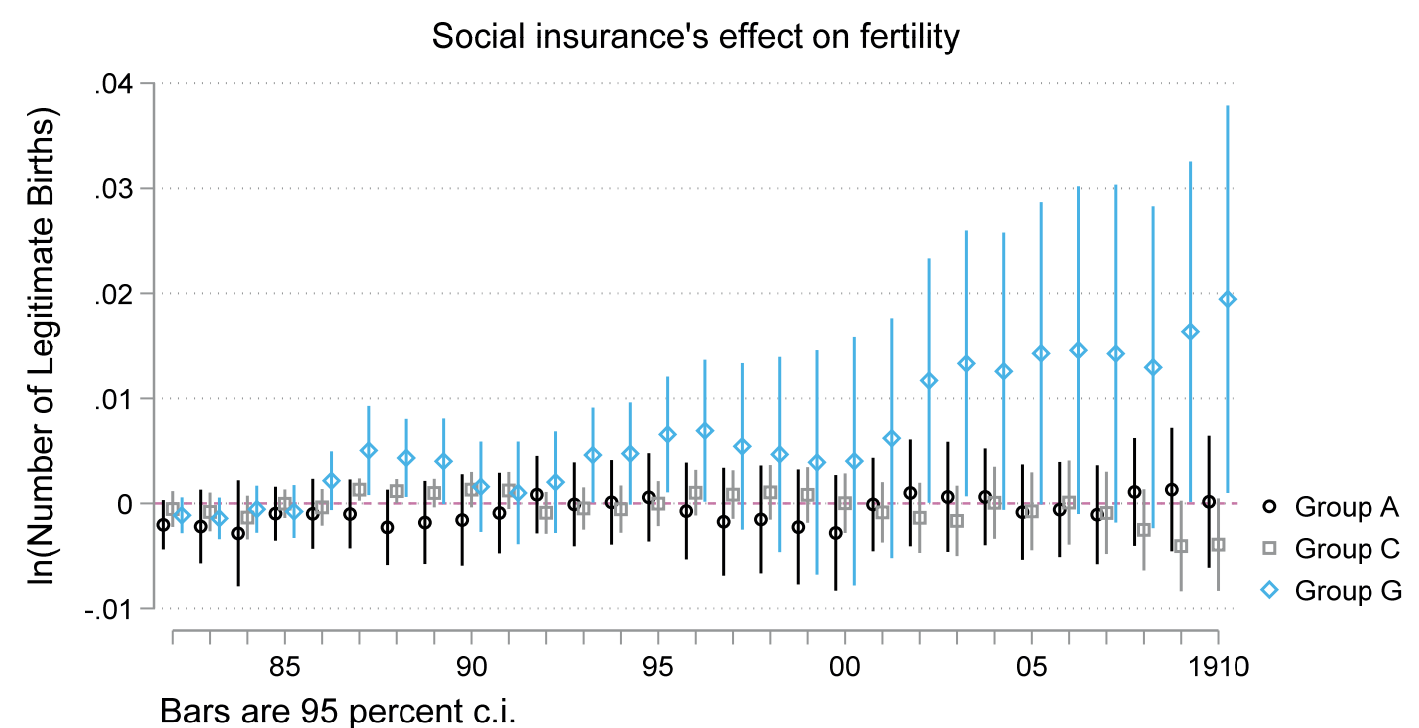

Group A: Health 1883, accident 1884, pension 1891

Group C: No health, accident 1886, pension 1891

Group G: miners (insurance pre-dates Bismarck)

Note: The figure graphs the point-estimates and 95 percent confidence intervals for the regressions discussed in the text. Regression results are in Appendix J. 
Table 1: Contributions and benefits under the social insurance system

Health Insurance

Contributions - Two thirds by employer, one third by employees

\section{Accident Insurance}

Fully by employers
Old Age Pension Insurance

- $\quad$ One half by employers, one half by employees

- Additional governmental subsidy (50 marks per pensioner)

- Disability pension (approx. 20 percent of the last earnings ${ }^{1}$ )

- $\quad$ Old age pension at age of 70 (approx. 20 percent of the last earnings ${ }^{1}$ ) - Widow's pension for white-collar workers after 1912, for blue-collar workers after 1927 treatment for wife and children (voluntary additional benefits)

- $\quad$ Sick pay for up

- Medical treatment including physician's fees women in childbirth

- $\quad$ Funeral benefits (aditional benefits)
- Disability pension (up to two thirds of the last earnings)

- Widow's pension (20 percent of her husband's last earnings) until she remarried - Orphan's pension (each child received 15 percent of the worker's earnings until the age of 15) - Total survivors' benefits could not exceed 60 percent of the worker's last earnings

${ }^{1}$ Frerich, Johannes and Martin Frey (1996): Handbuch der Geschichte der Sozialpolitik in Deutschland, Vol. 1: Von der vorindustriellen Zeit bis zum Ende des Dritten Reiches, Oldenbourg Verlag, Munich/Vienna, p. 106. 
Table 2: Occupational groups defined by treatment status

\begin{tabular}{|c|c|c|c|}
\hline Group & Who & Insurance coverage & $\begin{array}{l}\text { Percent of labor } \\
\text { force (in 1882) }\end{array}$ \\
\hline A & $\begin{array}{l}\text { Industrial } \\
\text { workers and } \\
\text { white-collar } \\
\text { workers }\end{array}$ & $\begin{array}{l}\text { Health insurance } \\
1884 \\
\text { Accident insurance } \\
1885 \\
\text { Pension insurance } \\
1891\end{array}$ & 22.75 \\
\hline B & $\begin{array}{l}\text { Construction } \\
\text { workers }\end{array}$ & $\begin{array}{l}\text { Health insurance } \\
1884 \\
\text { Accident insurance } \\
1887 \\
\text { Pension insurance } \\
1891\end{array}$ & 4.43 \\
\hline $\mathrm{C}$ & $\begin{array}{l}\text { Farm workers } \\
\text { (employees, not } \\
\text { farmers) }\end{array}$ & $\begin{array}{l}\text { Accident insurance } \\
1886 \\
\text { Pension insurance } \\
1891\end{array}$ & 24.41 \\
\hline $\mathrm{D}$ & $\begin{array}{l}\text { Domestic } \\
\text { servants }\end{array}$ & $\begin{array}{l}\text { Pension insurance } \\
1891\end{array}$ & 8.1 \\
\hline $\mathrm{E}$ & Public servants & $\begin{array}{l}\text { Government aid when } \\
\text { sick or old since } 1825 \\
\text { Accident insurance } \\
1886\end{array}$ & 1.0 \\
\hline $\mathrm{F}$ & $\begin{array}{l}\text { The self- } \\
\text { employed, } \\
\text { including farmers }\end{array}$ & $\begin{array}{l}\text { No social insurance in } \\
\text { our period }\end{array}$ & 36.23 \\
\hline G & Miners & $\begin{array}{l}\text { Treated prior to } \\
\text { Bismarck }\end{array}$ & 3.06 \\
\hline
\end{tabular}

Note: In group A, high-paid white-collar workers are included (although not treated) because we cannot distinguish them from low-paid white-collar workers in the statistics. See text for discussion of Group "D" especially. The final column is defined as in the regressions reported in the text. 
Table 3: Treatment groups in three example districts

\begin{tabular}{lllllllllll} 
Kreis & Region & \multicolumn{3}{c}{ Group (in percent) } & & & & & CBR & CBR \\
& & A & B & C & D & E & F & G & 1880 & 1895 \\
Düren & Rhineland & 30.69 & 3.08 & 25.17 & 5.90 & 0.63 & 32.31 & 2.22 & 36.6 & 35.8 \\
Hagen & Ruhr & 39.37 & 4.49 & 7.50 & 7.36 & 0.67 & 29.59 & 11.03 & 40.9 & 37.9 \\
(Land) & region & & & & & & & & & \\
Schivelbein & West & 5.58 & 3.87 & 44.05 & 9.42 & 0.81 & 36.07 & 0.21 & 34.9 & 30.1 \\
& Pomerania & & & & & & & & &
\end{tabular}


Table 4: Differences in differences for the marriage model

\begin{tabular}{|c|c|c|c|c|c|c|}
\hline $\begin{array}{l}\text { Groups } \\
\text { tested }\end{array}$ & $\begin{array}{l}\text { Logic of the } \\
\text { comparison }\end{array}$ & 1890 & 1895 & 1900 & 1905 & 1910 \\
\hline A v. F & $\begin{array}{c}\text { Full Bismarck } \\
\text { treatment } \\
\text { compared to } \\
\text { no insurance }\end{array}$ & $\begin{array}{l}.56 \\
.006\end{array}$ & $\begin{array}{l}.37 \\
.006\end{array}$ & $\begin{array}{l}.79 \\
.004\end{array}$ & $\begin{array}{l}.07 \\
.001\end{array}$ & $\begin{array}{l}.17 \\
.001\end{array}$ \\
\hline A v. C & $\begin{array}{l}\text { No health } \\
\text { insurance }\end{array}$ & $\begin{array}{c}0 \\
.001\end{array}$ & $\begin{array}{c}0 \\
.001\end{array}$ & $\begin{array}{c}0 \\
0 \\
.005\end{array}$ & $\begin{array}{c}0 \\
.006\end{array}$ & $\begin{array}{c}0 \\
.005\end{array}$ \\
\hline A v. D & $\begin{array}{l}\text { No health or } \\
\text { accident } \\
\text { insurance }\end{array}$ & $\begin{array}{l}.47 \\
.002\end{array}$ & $\begin{array}{c}.21 \\
-.001\end{array}$ & $\begin{array}{l}.61 \\
.002\end{array}$ & $\begin{array}{c}.28 \\
-.001\end{array}$ & $\begin{array}{l}.23 \\
-.002\end{array}$ \\
\hline $\mathrm{D}$ v. F & $\begin{array}{l}\text { Pension alone } \\
\text { versus no } \\
\text { coverage }\end{array}$ & $\begin{array}{l}.28 \\
.008\end{array}$ & $\begin{array}{l}.09 \\
.012\end{array}$ & $\begin{array}{l}.68 \\
.007\end{array}$ & $\begin{array}{l}.71 \\
.007\end{array}$ & $\begin{array}{l}.49 \\
.008\end{array}$ \\
\hline E v. G & $\begin{array}{c}\text { Two variants } \\
\text { on pre- } \\
\text { Bismarck } \\
\text { coverage }\end{array}$ & $\begin{array}{c}.66 \\
-.011\end{array}$ & $\begin{array}{c}.35 \\
-.025\end{array}$ & $\begin{array}{c}.09 \\
-.057\end{array}$ & $\begin{array}{l}.11 \\
-.065\end{array}$ & $\begin{array}{l}.17 \\
-.053\end{array}$ \\
\hline A v. G & $\begin{array}{l}\text { Full Bismarck } \\
\text { versus } \\
\text { Knappschaften }\end{array}$ & $\begin{array}{l}.99 \\
-.002\end{array}$ & $\begin{array}{c}.61 \\
-.001\end{array}$ & $\begin{array}{c}.40 \\
0\end{array}$ & $\begin{array}{c}.56 \\
-.001\end{array}$ & $\begin{array}{l}.55 \\
-.001\end{array}$ \\
\hline A v. E & $\begin{array}{l}\text { Full Bismarck } \\
\text { versus civil- } \\
\text { service status }\end{array}$ & $\begin{array}{l}.66 \\
-.021\end{array}$ & $\begin{array}{l}.34 \\
-.006\end{array}$ & $\begin{array}{l}.08 \\
.027\end{array}$ & $\begin{array}{l}.10 \\
.034\end{array}$ & $\begin{array}{l}.15 \\
.022\end{array}$ \\
\hline A v. B & $\begin{array}{l}\text { Two variants } \\
\text { on full } \\
\text { Bismarck }\end{array}$ & $\begin{array}{l}.55 \\
.002\end{array}$ & $\begin{array}{l}.62 \\
.002\end{array}$ & $\begin{array}{l}.49 \\
.001\end{array}$ & $\begin{array}{c}.22 \\
-.003\end{array}$ & $\begin{array}{c}.36 \\
-.001\end{array}$ \\
\hline
\end{tabular}

Notes: The first number in each cell is the p-value from the two-sided test of the null hypothesis that DD equals zero, where $\mathrm{DD}$ is defined as (for example) $\left(\mathrm{A}_{1910^{-}} \mathrm{C}_{1910}\right)-\left(\mathrm{A}_{1882}-\mathrm{C}_{1882}\right)$. The second number in each cell is the magnitude of DD. The base year in this table is always 1882; see appendix Table H.3 for other base years. 
Table 5: Differences in differences for the fertility model

\begin{tabular}{|c|c|c|c|c|c|c|}
\hline $\begin{array}{l}\text { Groups } \\
\text { tested }\end{array}$ & $\begin{array}{l}\text { Logic of the } \\
\text { comparison }\end{array}$ & 1890 & 1895 & 1900 & 1905 & 1910 \\
\hline A v. F & $\begin{array}{l}\text { Full Bismarck } \\
\text { treatment } \\
\text { compared to } \\
\text { no insurance }\end{array}$ & $\begin{array}{c}.73 \\
0\end{array}$ & $\begin{array}{l}.10 \\
.003\end{array}$ & $\begin{array}{c}.87 \\
-.001\end{array}$ & $\begin{array}{l}.73 \\
.002\end{array}$ & $\begin{array}{l}.68 \\
.001\end{array}$ \\
\hline A v. C & $\begin{array}{l}\text { No health } \\
\text { insurance }\end{array}$ & $\begin{array}{c}.45 \\
0\end{array}$ & $\begin{array}{l}0.20 \\
.003\end{array}$ & $\begin{array}{c}.61 \\
0\end{array}$ & $\begin{array}{l}.57 \\
.002\end{array}$ & $\begin{array}{l}.12 \\
.007\end{array}$ \\
\hline A v. D & $\begin{array}{l}\text { No health or } \\
\text { accident } \\
\text { insurance }\end{array}$ & $\begin{array}{c}.99 \\
-.012\end{array}$ & $\begin{array}{l}.76 \\
-.015\end{array}$ & $\begin{array}{c}.70 \\
-0.160\end{array}$ & $\begin{array}{c}.59 \\
-.019\end{array}$ & $\begin{array}{l}.25 \\
-.030\end{array}$ \\
\hline D v. F & $\begin{array}{l}\text { Pension alone } \\
\text { versus no } \\
\text { coverage }\end{array}$ & $\begin{array}{c}.02 \\
0\end{array}$ & $\begin{array}{l}.36 \\
.005\end{array}$ & $\begin{array}{l}.73 \\
.002\end{array}$ & $\begin{array}{l}.51 \\
.007\end{array}$ & $\begin{array}{l}.22 \\
.018\end{array}$ \\
\hline Ev. G & $\begin{array}{c}\text { Two variants } \\
\text { on pre- } \\
\text { Bismarck } \\
\text { coverage }\end{array}$ & $\begin{array}{l}.39 \\
-.100\end{array}$ & $\begin{array}{l}.05 \\
-.007\end{array}$ & $\begin{array}{c}.82 \\
-.023\end{array}$ & $\begin{array}{c}.83 \\
-.026\end{array}$ & $\begin{array}{l}.80 \\
.030\end{array}$ \\
\hline A v. G & $\begin{array}{l}\text { Full Bismarck } \\
\text { versus } \\
\text { Knappschaften }\end{array}$ & $\begin{array}{c}.46 \\
0\end{array}$ & $\begin{array}{l}.13 \\
-.003\end{array}$ & $\begin{array}{c}.37 \\
-.004\end{array}$ & $\begin{array}{l}.06 \\
-.012\end{array}$ & $\begin{array}{c}.04 \\
-.016\end{array}$ \\
\hline A v. E & $\begin{array}{c}\text { Full Bismarck } \\
\text { versus civil- } \\
\text { service status }\end{array}$ & $\begin{array}{l}.39 \\
.157\end{array}$ & $\begin{array}{l}.93 \\
.061\end{array}$ & $\begin{array}{l}.86 \\
.072\end{array}$ & $\begin{array}{l}.91 \\
.071\end{array}$ & $\begin{array}{l}.66 \\
.011\end{array}$ \\
\hline A v. B & $\begin{array}{l}\text { Two variants } \\
\text { on full } \\
\text { Bismarck }\end{array}$ & $\begin{array}{l}.59 \\
.005\end{array}$ & $\begin{array}{l}.56 \\
.006\end{array}$ & $\begin{array}{l}.26 \\
.012\end{array}$ & $\begin{array}{l}.06 \\
.022\end{array}$ & $\begin{array}{l}.02 \\
.036\end{array}$ \\
\hline
\end{tabular}

Notes: See the notes to Table 4. Based on a just-identified 2SLS model that treats infant mortality and marriage as endogenous. 
Table 6: Differences in differences for the marriage model, urban

\begin{tabular}{|c|c|c|c|c|c|c|}
\hline $\begin{array}{l}\text { Groups } \\
\text { tested }\end{array}$ & $\begin{array}{l}\text { Logic of the } \\
\text { comparison }\end{array}$ & 1890 & 1895 & 1900 & 1905 & 1910 \\
\hline A v. F & $\begin{array}{l}\text { Full Bismarck } \\
\text { treatment } \\
\text { compared to } \\
\text { no insurance }\end{array}$ & $\begin{array}{c}0 \\
.010\end{array}$ & $\begin{array}{c}0 \\
.010\end{array}$ & $\begin{array}{l}.01 \\
.009\end{array}$ & $\begin{array}{c}.04 \\
0.007\end{array}$ & $\begin{array}{l}.01 \\
.010\end{array}$ \\
\hline A v. C & $\begin{array}{l}\text { No health } \\
\text { insurance }\end{array}$ & $\begin{array}{c}0 \\
.006\end{array}$ & $\begin{array}{c}0 \\
0 \\
.007\end{array}$ & $\begin{array}{c}0 \\
011\end{array}$ & $\begin{array}{c}0 \\
.013\end{array}$ & $\begin{array}{c}0 \\
.013\end{array}$ \\
\hline A v. D & $\begin{array}{l}\text { No health or } \\
\text { accident } \\
\text { insurance }\end{array}$ & $\begin{array}{c}0 \\
-.005\end{array}$ & $\begin{array}{c}0 \\
-.009\end{array}$ & $\begin{array}{c}0 \\
-.011\end{array}$ & $\begin{array}{c}0 \\
-.017\end{array}$ & $\begin{array}{l}.06 \\
-.012\end{array}$ \\
\hline $\mathrm{D}$ v. F & $\begin{array}{l}\text { Pension alone } \\
\text { versus no } \\
\text { coverage }\end{array}$ & $\begin{array}{c}0 \\
.025\end{array}$ & $\begin{array}{c}0 \\
.030\end{array}$ & $\begin{array}{c}0 \\
.030\end{array}$ & $\begin{array}{c}0 \\
.034\end{array}$ & $\begin{array}{l}.01 \\
.032\end{array}$ \\
\hline Ev. G & $\begin{array}{c}\text { Two variants } \\
\text { on pre- } \\
\text { Bismarck } \\
\text { coverage }\end{array}$ & $\begin{array}{c}.69 \\
-.012\end{array}$ & $\begin{array}{l}.26 \\
-.045\end{array}$ & $\begin{array}{c}.11 \\
-.078\end{array}$ & $\begin{array}{l}.05 \\
-.105\end{array}$ & $\begin{array}{c}.38 \\
-.052\end{array}$ \\
\hline A v. G & $\begin{array}{l}\text { Full Bismarck } \\
\text { versus } \\
\text { Knappschaften }\end{array}$ & $\begin{array}{l}.03 \\
.003\end{array}$ & $\begin{array}{l}.05 \\
.004\end{array}$ & $\begin{array}{l}.01 \\
.008\end{array}$ & $\begin{array}{l}.01 \\
.007\end{array}$ & $\begin{array}{l}.01 \\
.009\end{array}$ \\
\hline A v. E & $\begin{array}{c}\text { Full Bismarck } \\
\text { versus civil- } \\
\text { service status }\end{array}$ & $\begin{array}{c}.54 \\
-.013\end{array}$ & $\begin{array}{l}.21 \\
.019\end{array}$ & $\begin{array}{l}.07 \\
.057\end{array}$ & $\begin{array}{l}.03 \\
.083\end{array}$ & $\begin{array}{l}.28 \\
.032\end{array}$ \\
\hline A v. B & $\begin{array}{l}\text { Two variants } \\
\text { on full } \\
\text { Bismarck }\end{array}$ & $\begin{array}{c}.55 \\
-.001\end{array}$ & $\begin{array}{l}.35 \\
-.005\end{array}$ & $\begin{array}{l}.45 \\
-.004\end{array}$ & $\begin{array}{l}.26 \\
-.009\end{array}$ & $\begin{array}{l}.30 \\
-.008\end{array}$ \\
\hline
\end{tabular}

Notes: See notes to Table 4 . The regression sub-sample on which these estimates are based is limited to Kreise that were at least 30 percent urban in 1880. 